Scientia Militaria vol 40, no 3, 2012, pp.109-146. doi: 10.5787/40-3-1030

\title{
The Suppression of Internal Unrest in South West Africa (Namibia) 1921-1933
}

\author{
Andries M. Fokkens
}

\begin{abstract}
In 1915, the Union of South Africa was requested to administrate South West Africa (SWA) (today Namibia) on behalf of the British Crown and approved the South West Africa Mandate. The policies of the Union strongly influenced the administration of SWA, and the administration met with indigenous opposition discontent with the maltreatment. An attitude of master and servant was prevalent in the mandated territory and the maltreatment of the indigenous people in the mandated territory, racial prejudice, double standards in executing branding laws, enforced indentured labour, dog and hut tax were some of the grievances that the Bondelswarts, the Rehoboth Basters and the Ukuambi had against the SWA Administration. The Administration perceived these actions as internal unrest and subdued it using police and military resources.
\end{abstract}

Suppressing unrest through force was part of the military policing tradition prevalent in Southern Africa and abroad during the colonial era. The tactical deployment of ground forces in conjunction with aircraft was an innovation that transformed future operations in SWA between the suppression of the Bondelswarts and the actions against Chief Ipumbu.

This article discusses the utilisation of the Union Defence Force (UDF) and South West Africa Forces against indigenous people of South West Africa between the two world wars focusing on three incidents over the period 1922 to 1932. Tactical deployments of ground forces and the

Andries M. Fokkens (MMil in Military History) holds an administrative position at the Faculty of Military Science, Stellenbosch University. 
application of air power in support of ground forces to suppress internal unrest are explained and discussed. These discussions provide the military historian with salient facts on physical conditions encountered, the tactics employed and the role of a new weapon system, aircraft, yet to be fully understood in its role as a force multiplier.

Keywords: internal unrest, aircraft, tactical deployments, Bondelswarts, Rehoboth, Ukuambi, Ipumbu, SWA (South West Africa), Namibia

\section{Introduction}

The Union of South Africa invaded German South West Africa (today Namibia) during the First World War to protect British strategic interests. Between 1915 and 1920, the territory was occupied by the Union Defence Force (UDF) and managed as a military protectorate with E.H.L. Gorges as Administrator to advise the military in managing the territory. In the aftermath of World War I, German colonies were classified as A-, B- or Cclass mandates, depending on the indigenous population's stage of development, the colony's geographical position, its economic condition, etc. SWA became a C-class mandate and entrusted to the British Crown. The Union of South Africa was requested to administrate South West Africa (SWA) on behalf of the British Crown, and approved the South West Africa Mandate Act No. 49 of 1919. The mandate was signed on 17 December 1920, martial law was recalled and the civilian administration was awarded the authority to rule South West Africa as a mandated territory from 1 January $1921 .{ }^{1}$

The mandate conferred full power of administration and legislation on South Africa and stated that the territory was an integral portion of the Union of South Africa and could apply laws of the Union of South Africa with local modifications as circumstances may require. Various other requirements were set, which prohibited slavery, forced labour, supply of intoxicating spirits and beverages and military training other than protecting the territory. The League of Nations emphasised social development and the enhancement of material and moral wellbeing of the indigenous populations. G.R. Hofmeyer replaced Gorges as the Administrator-General and reported to the Prime Minister of the Union who in turn was to provide annual 
reports to the Council of the League of Nations on measures taken to fulfil the Mandate of South West Africa. ${ }^{2}$

The policies of the Union strongly influenced the administration of SWA. Silvester, Wallace and Hayes argue that SWA policies regarding indigenous populations were formed using existing Union policies that regulated the flow of labour and control over indigenous populations. ${ }^{3}$ An attitude of master and servant was obvious in the mandated territory and Tony Emmet refers to a report from a military magistrate in 1920 that notes the attitude of a white farmer perceiving the indigenous population as subhuman, and which must receive a hiding once a day to ensure their obedience. ${ }^{4}$ The maltreatment of the indigenous people in the mandated territory, racial prejudice, double standards in executing branding laws, enforced indentured labour, dog and hut tax were some of the grievances that the Bondelswarts, the Rehoboth Basters and the Ukuambi had against the SWA Administration. ${ }^{5}$

Their grievances were not attended to by the Administration who perceived it as direct opposition to administrative authority. New political organisations like the Industrial and Commercial Workers Union (ICU, 1921), the African People's Organisation (APO, 1922) and the South West Africa National Congress (SWANC, 1922) within urban centres increased anxieties that the indigenous population would unite politically and contest for suffrage and self-determination for the whole of SWA. ${ }^{6}$ The Bondelswarts, Rehoboth and the Ukuambi discussed their respective grievances with the Administration, who refused to repeal the laws causing the grievance and enforced their authority through the application of force. The Administration perceived these actions as internal unrest and subdued it using police and military resources.

Literature on indigenous uprisings in South West Africa during the inter-war period is informative and provides insight into social structures and the political background of the uprisings, but lack detail regarding tactical deployments, force strength, weapons used and challenges faced. This article serves to enhance the available literature with such additional information. Valuable background information was found in literature pertaining to Namibian history such as Namibia: The violent heritage (1986) by D. Soggot, A history of resistance in Namibia (1988) by P.H Katjavivi, 
and T. Emmett's book, Popular resistance and the roots of nationalism in Namibia, 1915-1966 (1999), but it offered very little for the military historian. In R. Freislich's The last tribal stand: A history of the Bondelswart uprising (1964), the Bondelswarts uprising is described in detail. It also receives attention in A.M. Davey's The Bondelswarts affair (1961) and G.L.M. Lewis's unpublished MA thesis, "The Bondelswarts rebellion of 1922" (1977) that contextualises the political and social issues associated with the uprising, but which is limited in its ability to contextualise military manoeuvres.

There are useful sources available on the Rehoboth "Basters" such as P. Pearson's The history and social structure of the Rehoboth Baster community of Namibia (1985), R.G. Britz's A concise history of the Rehoboth Basters until 1990 (1999) and an unpublished D Litt thesis by G.J.J. Oosthuizen, "Die Rehoboth-basters binne die konteks van die staatkundige verhoudinge tussen Suidwes-Afrika en Suid-Afrika, 19151939” (1993). These sources expand greatly on political and social issues, but do not cover the use of military force with significant detail. The uprising and suppression of the Ukuambi tribe in 1932 is mostly discussed in government reports delivered to Parliament and very little published literature was traced.

This article addresses the shortfall in published literature on tactical deployments, and the author derived great insight from archival sources in the National and the SA National Defence Force (SANDF) Archives that provided reports and correspondence illustrating the tactical deployment of Union forces. The most useful archive groups at the National Archives of South Africa are the archives of the Secretary of Native Affairs, the archives of the Governor-General, the archives of the Minister of Justice, the archives of the South African Party and the archives of the Prime Minister. The most informative archive groups at the SANDF Archives are the "Accessions" and the archives of the Adjutant General, the Chief of the General Staff, the Secretary of Defence, the Chief of Defence Force Administration and the Union War Histories.

This article discusses the utilisation of the Union Defence Force (UDF) and South West Africa Forces against indigenous people of South West Africa between the two World Wars focusing on three incidents over 
the period 1922 to 1932 . The heritage of military policing is briefly discussed to contextualise the role the police and military forces played during times of peace to police the urban and rural areas respectively within the Union and SWA. The SWA Administration applied many Union policies and legislation to their own conditions and found opposition to them from the Bondelswarts and the Rehoboth. Chief Ipumbu openly opposed the administration's authority and was a destabilising influence in Ovamboland. Instead of focusing on their grievances, military force was applied in a calculated manner to suppress the uprisings quickly and with minimum loss of life. These actions were heavily criticised by opposition parties in the Union as well as the Permanent Mandates Commission who viewed these actions as contrary to the essence of administering a mandate. This article is not a social or political history per se, but a military history of the Union of South Africa and South West Africa's military forces to suppress internal unrest in South West Africa as a mandated territory of the Union between the two world wars from 1922 to 1932. Tactical deployments of ground forces and the application of air power in support of ground forces to suppress internal unrest are explained and discussed. These discussions provide the military historian with salient facts on physical conditions encountered, the tactics employed and the role of a new weapon system, namely aircraft, which had yet to be fully understood in its role as a force multiplier.

\section{The Heritage of Military Policing in South Africa and its Application in South West Africa}

The gradual colonisation of South Africa had a direct effect on the indigenous population of South West Africa. They faced the dilemma of either displacement or integration. Whatever choices were made profoundly affected them. Tribal cohesion and traditional values were lost in the constant battle to regain the land taken from them by the colonists. The use of military power was instrumental in facilitating the growth of Jan van Riebeeck's small refreshment post into a thriving colony at the southern tip of Africa. These actions did not only include military expeditions, but also the policing of the settled areas by militant means. ${ }^{7}$ South Africa is not unique in this policing tradition, as this was the norm for many western colonial powers. 
The European colonisation of the various African territories was met with fierce indigenous resistance. Germany consistently carried out military expeditions in German East Africa from 1889 to 1907, including the MajiMaji (1905-1907) as well as German South West Africa with the Herero revolt from 1904-1907. The indigenous populations of West and NorthCentral Africa bravely resisted French colonisation, but were eventually suppressed by French colonial forces. Resistance was especially fierce in Algeria (1903-1910) and Morocco (1912-1934). British colonisation in West Africa encountered fierce resistance from the indigenous populations of Nigeria (1892-1902) and the Gold Coast (1895-1900), as was the case in South Africa. The Basutos (1868), the Xhosas (1878), the Pedi and the Zulus (1879), the Boers of the Transvaal and the Orange Free State (18991902) and other groups resisted this colonial drive, but eventually all succumbed to European rule. ${ }^{8}$

The military played a significant role in suppressing the uprisings in the various colonies and the general approach of colonial forces in the late $19^{\text {th }}$ and early $20^{\text {th }}$ centuries was that the use of extreme force and superior firepower was an appropriate response to suppress the uprising of local inhabitants. Technological advances enabled expanding colonial communities to counter indigenous resistance to white settlement successfully. Indigenous weapons, such as the bow and arrow and the spear were overwhelmed by colonial firepower. The technologically disadvantaged indigenous populations were subjugated eventually by the use of military force and firepower. Steamships, prophylaxes, developments in communications and modern weapons, such as air power and the machine gun, assisted the Europeans to consolidate their power. A few examples were the Xhosas who were beaten decisively in 1878 after nine frontier wars, the Pedi and the Zulus who were subjugated in 1878 and 1879, and in 1885 control was established over the Tswana-speaking people and their territory. Firepower was the key to ensuring the settlement of South Africa by populations migrating from Europe. ${ }^{9}$

The justification to use force to suppress indigenous communities in South West Africa was derived from a combined heritage of British and Boer military policing attitudes prevalent in the Union of South Africa, where force was applied by the British through their Empire to enforce peace and by the Boers to pacify the rural environment and protect their 
agricultural interests. The structures that facilitated the victories were the British military regiments and the Boer commandos. John Brewer states, "Police bodies in South Africa began as colonial forces [...] and retained most of the features of this model as the $20^{\text {th }}$ century progressed., 10

Brewer further states, "Union was in part an act of decolonisation for Whites, but it left a tremendous task of internal colonialism in monitoring, regulating and controlling the Black population." ${ }^{11}$ This reflects the need of the state to have a police force to continue the regulation of race relations, but also to have a modern police force to police whites. The formation of the South African Mounted Riflemen (SAMR) and the SA Police implied two separate police forces each with its own jurisdiction, function and style. The military policing tradition of the paramilitary and civil police forces in South Africa before 1910 was passed on in 1912 to the newly formed Union Defence Force (UDF). The new SAMR, the Permanent Force of the UDF under Brig. Gen. H.T. Lukin, consisted of five regiments and was formed from parts of the old colonial police and military units, which continued their original policing duties after formation. ${ }^{12}$

The SA Police and the SAMR were responsible for policing the urban and the rural areas respectively. The construction of the SAMR was a product of its time as a solution to the policing of the indigenous populations in the rural areas. The SAMR was mounted, paramilitary in style and was intended for military service during times of war, but in times of peace, it was used exclusively to police the black population. As a military unit, it was better equipped than the police to enforce law and order in black areas and to deal with black resistance to white domination. After the SAMR had been promulgated under the 1912 Defence Act, rural policing was the responsibility of the UDF. ${ }^{13}$

The method in dealing with indigenous unrest was clearly stipulated, as instructed by the Prime Minister to the UDF, in a 1918 notice to all district staff officers. The magistrates and native commissioners were to be involved in the process with instructions to report and await instructions. The UDF's policing role manifested in various ways and included show of force to distant rural settlements as well as dispersing indigenous mineworkers on strike. In 1919, they dispersed the strikers of the SA Collieries at Dundee, Utrecht and Pietermaritzburg while the Under- 
secretary for Native Affairs requested the SAMR in Springbok to deal with an armed indigenous group squatting on the SWA and Union border. ${ }^{14}$ Two years later, in 1921, the UDF supported the SA Police in dispersing the Israelites from Bulhoek at Queenstown. ${ }^{15}$ Military force was not exclusively used against indigenous populations, but also against white mineworkers in 1913, 1914 and again in 1922. The Rebellion of 19141915, consisting of mainly white Boers who were veterans of the Second Anglo-Boer War, was also suppressed. ${ }^{16}$

The UDF in SWA continued its policing role under the martial law that governed the military protectorate from 1915 to 1920. Members of the UDF's SAMR, who served in SWA at the end of 1919, were seconded to the SWA Administration to form the SWA military force. The SWA Police was formed as a separate force with the South African Police Act and system applied to it, with the SAMR Military Constabulary present in SWA forming the backbone of its rank and file. Those members who were not selected were demobilised on 31 March 1920. The head of the SWA Police was a deputy commissioner chosen by the commissioner and seconded to the Administration. ${ }^{17}$ The military and police forces in SWA mirrored the UDF and SA Police respectively in role and function. It is therefore not surprising that these forces were called to action in 1922 against the Bondelswarts.

\section{The Uprising of the Bondelswarts, May to June 1922}

The Bondelswarts, indigenous to the South West African region, known today as Southern Namibia and the Northern Cape in South Africa, were the masters of the south before the German occupation. They were a nomadic, pastoral people whose stock consisted of goats and cattle with their main sustenance derived from the hunting of game. The Bondelswarts were defeated in a protracted war against the Germans from 1903 to 1906, but their reputation as fierce, ruthless and cunning fighters was confirmed. In their natural stronghold, the Fish River Canyon, they employed guerrilla tactics to good effect to keep the German forces at bay. Jacobus Cristiaan and Abraham Morris were leading figures amongst the Bondelswarts during their conflict. Cristiaan was the hereditary chief and Morris fought as a captain. He made a name for himself as being a capable and resourceful leader and a master of guerrilla tactics. Both feared retribution from the 
Germans and fled across the Orange River into the Northern Cape after a peace treaty was signed, where they stayed until after the War. ${ }^{18}$

The Bondelswarts expected the new Administration to abolish the restrictions of the German treaty, but the conditions of the treaty were only confirmed. Resentment towards the Administration as well as prevailing economic hardships during a drought fermented dissent amongst the impoverished Bondelswarts who complained they had, "only exchanged one yoke for another". ${ }^{19}$ Their grievances towards the Administration included

(a) The discriminatory practice to have the white farmers keep their cattle branding irons whereas they were not allowed for the prevention of stock theft;

(b) A concerted effort to invent and apply dog taxes and hunting regulations to impoverish the Bondelswarts and force them to work under the old German regulation that stated indigenous men had to enter the labour market if they had no visible means of support. Interpreted by the Administration as having less than ten head of cattle or fifty head of small stock, many indigenous people sought work in the towns where access was strictly controlled and no vagrancy allowed. Many were forced to seek work on commercial farms;

(c) Viewing the police with suspicion and fear as well as experiencing them as harsh, provocative and unnecessarily severe. The police, on the other hand, viewed the Bondelswarts as insolent, lazy and thievish. The general view of the police was that they were policing a subservient race and insolence was rewarded with flogging;

(d) Land allocation discrepancies between the Bondelswarts sketch provided to them by the German Commission and the official survey map which the Administration accepted as the true reflection of boundaries that severely limited their lands for grazing; and

(e) The Administration's refusal to acknowledge tribal leadership when their true chief Jacobus Cristiaan returned in 1919. They reconfirmed the appointment of Timothy Beukes and charged Cristiaan as illegal alien and for shipping cattle across the border 
without authorisation. The sentence of a $£ 100$ fine or 12 months' imprisonment was suspended, but antagonised many Bondelswarts. ${ }^{20}$

In 1922, fear of an indigenous uprising amongst the white farmers of the region created an atmosphere of paranoia in which any large movement by the Bondelswarts was seen as a possible mobilisation. Cristiaan and 50 of his followers were no exception. More Bondelswarts crossed the Orange River in the wake of Cristiaan's return. Their return sparked fears of unrest and the relationship between the Bondelswarts and the police, as well as the Bondelswarts and the white farmers, deteriorated. The tension reached breaking point with the return of Abraham Morris in April 1922. Morris embodied the fighting spirit of the Bondelswarts and he was given a hero's welcome when he arrived at Guruchas. The Native Affairs Commission was unable to ascertain the motive for his return to Guruchas, but his return was perceived by many Bondelswarts that they would rise again. He would lead them in tearing up the treaty and in the process reclaim what was rightfully theirs. Scores of Bondelswarts apparently believed some action would follow, converging on Haib and Guruchas soon after Morris had returned. ${ }^{21}$

However, his return was not kept secret. Cristiaan notified the Location Superintendent, Noothout, stationed at Driehoek, who in turn notified the magistrate at Warmbad. The information reached the ears of Hofmeyer, who issued instructions that Morris must be arrested and charged with

(a) Bringing sixteen rifles into the territory of SWA without permits;

(b) Bringing cattle over the border without a permit; and

(c) Entering the territory without a permit.

On 5 May 1922, Sgt Van Niekerk and Native Constable Gert Kraai were ordered to arrest Morris on these charges. Their attempt to arrest Morris was obstructed by the tribe. It was the opinion of the tribe that Morris had done nothing wrong and their champion would not go to gaol. Angry words were exchanged, which the Bondelswarts accepted as a declaration of war. The word of an impending conflict spread through the reserve, whereby the Bondelswarts converged on Haib and Guruchas with their stock, possessions and rifles. ${ }^{22}$ 
Attempts to lure Cristiaan and other Bondelswarts out of the reserve under false pretences of meetings were unsuccessful. Hofmeyer sent the Commissioner of Police in South West Africa, Maj. C.A. van Coller, under the flag of truce to negotiate an amiable solution, but at the same time mobilised volunteers undermining Van Coller's attempts. Hofmeyer's duality clouded the process of Van Coller's attempt to facilitate the arrest of Morris and four other members on related charges peacefully. Van Coller's discussions failed to deliver the members for arrest and by 20 May, Hofmeyer issued an ultimatum that called for Morris and four tribesmen to hand themselves over for trial, the surrender of all arms and ammunition and the obstruction of officers of the law to stop, or there would be dire consequences for the whole tribe. The Bondelswarts rejected the ultimatum and continued preparations for the coming conflict. Over the period 22 to 25 May 1922, various farms were raided for horses, supplies, rifles and ammunition. These raids included the house of the Superintendent of the Bondelswarts Reserve, Noothout, himself. The raids were executed at gunpoint, but nobody was injured or physically abused. In a separate incident, three Namas attacked and murdered Mrs Lydia Sarah Coleman on the farm Kubub near Lüderitz. This unrelated incident only heightened white fears and anti-Bondelswarts feelings. ${ }^{23}$

It was important for Hofmeyer to resolve the situation quickly and quietly for various reasons. He was in charge of a mandated territory and had to answer to the Union of South Africa. The Union in turn had to answer to the Permanent Mandates Commission of the League of Nations. A clash between Administration forces and an indigenous group, who they were supposed to develop and to hold in sacred trust, was an undesirable situation. However, a prolonged uprising by the Bondelswarts constituted the danger of further uprisings by other indigenous populations in the territory. This was even more undesirable and Hofmeyer did not wish to have to explain to Gen. Smuts why a general uprising had occurred. Hofmeyer was therefore reluctant to involve the Union in the matter and altruistically pointed out that the Union were still reeling from the Rand strike of 1922 and that the settlers in SWA had an opportunity to prove themselves worthy of the privileges they enjoyed by helping to suppress the uprising. Aid from the Union, however, was forthcoming and came in the form of two De Havilland D.H. 9 aeroplanes, two mountain guns and four Vickers machineguns with the respective personnel. Col. Sir P. van 
Ryneveld, Director Air Services, was in command of the aeroplanes. The Administration's forces mobilised and arrived at Kalkfontein South on 23 May. ${ }^{24}$

Hofmeyer, a former clerk of the Union House of Assembly, appointed himself commander of the combined force and bestowed upon himself the rank of colonel. Ironically, he was of the opinion that there was a lack of experienced commanders in the mandated territory and that he could not wait for the Union to send an able commander, because quick action was called for. However, the UDF did send a liaison officer with the support weapons, Maj. A.H. Prins, to assist Hofmeyer during the conflict. The volunteers arrived steadily at Kalkfontein South from the Gibeon, Keetmanshoop, Aroab and Warmbad districts and were grouped into squadrons. The Union contingent joined the Administration's force at Kalkfontein South on 26 May (see Table 1: Composition of the SWA Administration Force). Employing siege tactics against the Bondelswarts, Hofmeyer enveloped their positions at Guruchas and Haib by occupying the waterholes situated at Wortel, Driehoek, Dawigabis, Neufontein, Auputs and Norachas. He planned to deprive them of food and water and to cut off their retreat to the Orange River and the Fish River Canyon. ${ }^{25}$

\begin{tabular}{|l|c|c|c|}
\hline Unit & Officers & Other ranks & Total \\
\hline Headquarters & 5 & 4 & 9 \\
\hline A Squadron & 4 & 103 & 107 \\
\hline B Squadron & 4 & 88 & 92 \\
\hline C Squadron & 4 & 70 & 74 \\
\hline D Squadron & 2 & 47 & 49 \\
\hline Mountain gun section & 1 & 13 & 14 \\
\hline Machinegun section & 2 & 15 & 17 \\
\hline Signalling sections & & 8 & 8 \\
\hline Total & $\mathbf{2 2}$ & $\mathbf{3 4 8}$ & $\mathbf{3 7 0}$ \\
\hline
\end{tabular}

Table 1: The composition of the SWA Administration Force. ${ }^{26}$

South of the Orange River, forces from the Union prepared to intercept Bondelswarts crossing the border. The head of the South African Police in the Western Districts, Lt. Col. H.F. Trew, instructed 
reinforcements in the Steinkopf region to assist with border patrols. Smuts made it clear to Trew that the police were not allowed, under any circumstances, to cross the border and participate in the expedition against the Bondelswarts. Lt. Col. A.H.M. Nussey, the staff officer of the Potchefstroom Military District, was sent with orders by the Prime Minister to support the police and to prepare for the possible rapid deployment of volunteers in the event that military intervention became necessary. ${ }^{27}$

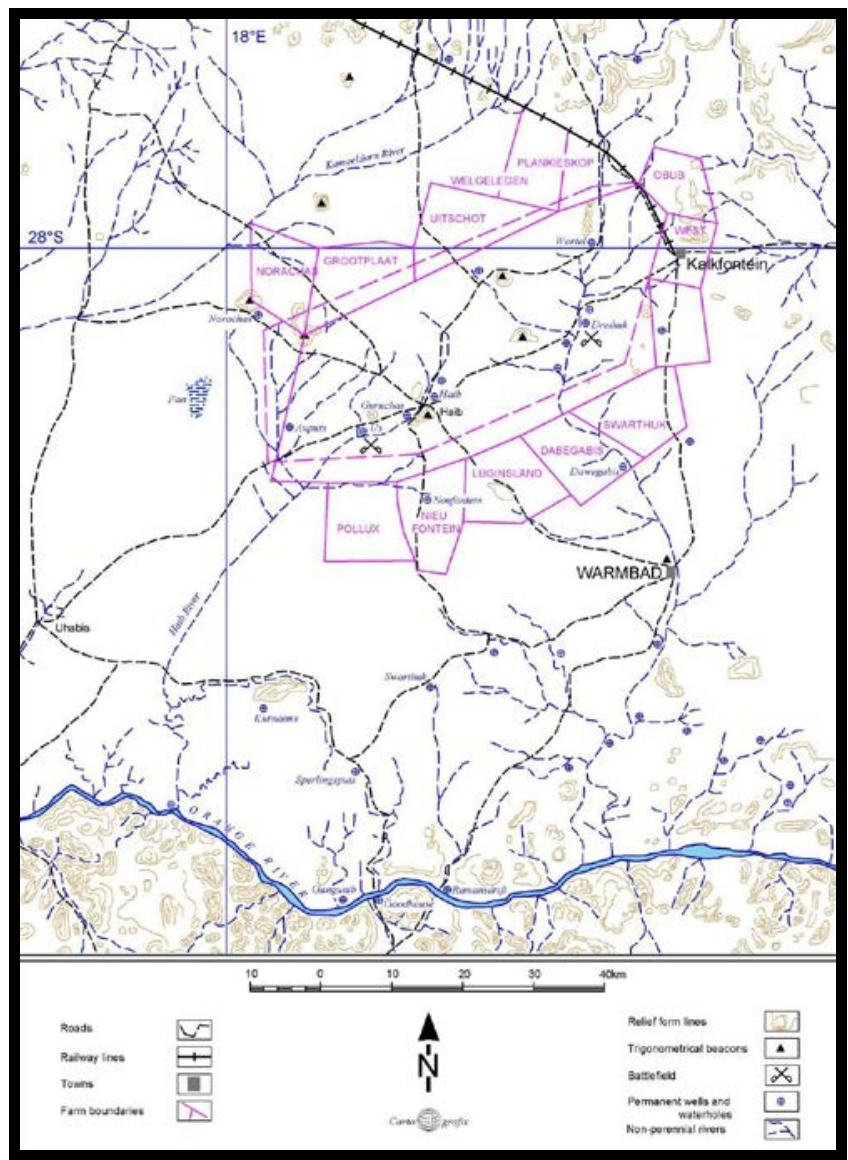

Figure 1: The Bondelswarts reserve. ${ }^{28}$ 
The Bondelswarts organised their hierarchy, with Cristiaan as the hereditary chief and Morris as the war chief with a few vice-captains. Each vice-captain was in charge of a commando, which was divided into sections. They still had a severe shortage of arms and ammunition, but their raiding strategy was to ambush the soldiers and relieve them of their weapons and ammunition. $^{29}$ During their war with the Germans, the Bondelswarts executed this tactic efficiently and they were hopeful of more successes. Morris sent Babab, also known as Klaas Isaacks, and Adam Pienaar to Driehoek and Wortel with a commando of 75 men to dominate the direct line of advance towards Guruchas from Kalkfontein South (see Figure 1). Morris accompanied by Beukes and a commando of 50 men, moved east towards Warmbad. Beukes later testified that their intention was to link up with the Warmbad Bondelswarts. An attack on Warmbad would divide Hofmeyer's force and divert his concentration from the reserve. Cristiaan and the rest of the Bondelswarts occupied the hilly western region of the reserve around Guruchas and Us. ${ }^{30}$

On 25 May, Capt. J.C. Balt marched with C Squadron, a machine gun section and a heliographic team on Norachas, after they had disembarked from the train at Klein Karas. On 26 May, Capt. Jordaan was ordered to occupy Driehoek and Wortel with D squadron, comprising 47 unmounted men, one machine gun and 21 mounted men. They were transported with trucks and were escorted to their objective by two troops of mounted rifles, Capt. Du Preez and Capt. Prinsloo each being in command of a troop. The advancing column of D Squadron narrowly missed an ambush laid by Babab at Driehoek. Their choice to take a higher route to avoid the soft sand, because of the vehicles, took them past the ambushing party, who in turn was caught off guard. A firefight ensued and the Bondelswarts were driven off without one rifle being captured. The pursuit had to be called off due to bad light. The advancing force had only one fatal casualty, but the Bondelswarts left three wounded, nineteen killed and nine prisoners behind. The prisoners were duly sent to Kalkfontein South. ${ }^{31}$

Upon hearing of the Bondelswarts' reverse at Driehoek, Morris immediately returned to Guruchas. His plan to fight on an extended front was abolished. The failure of the Bondelswarts to acquire more weapons and ammunition was a serious setback for their combat power, but Morris deployed the Bondelswarts in and around Guruchas in defensive positions, 
hoping to make the Administration's forces pay dearly for every inch of ground. The Bondelswarts numbered some 1100 people, with 600 cattle and 8000 small stock. $^{32}$

The troops of Du Preez and Prinsloo returned on the night of 26 May to prepare for the advance the following day. The next day, 27 May, A Squadron, two mountain guns, two machineguns and a heliograph section accompanied Hofmeyer and the HQ personnel as they advanced towards Neufontein via Dawigabis. Prinsloo and his troop provided the advance and the screens, while Du Preez was placed in charge of B Squadron, which covered the rear of the advancing column. On 28 May, the HQ was established at Neufontein. Prinsloo received orders to advance from Dawigabis towards Auputs on 27 May and joined Balt's C Squadron, which had advanced from Norachas towards Guruchas. Prinsloo's squadron took a direct line of advance towards Auputs, which took him past the waterhole Us, close to Guruchas. Pienaar ambushed Prinsloo and his men near Us on 28 May, but the trap was sprung too quickly. Prinsloo had one fatality and three wounded, while Pienaar was shot and killed. The Bondelswarts were driven off and the forces occupied all the waterholes around Guruchas. ${ }^{33}$

The Administration's forces surrounded Guruchas, and Hofmeyer attacked the stronghold on 29 May at 15:00. The mountain guns opened fire from a commanding position east of the objective as soon as the aeroplanes commenced their bombing. Machine gun and rifle fire accompanied the aerial and artillery bombardment. The aerial bombardment concentrated on enemy strong points and concentrated stock. Stock was very dear to the Bondelswarts and the subsequent killing of their stock was a severe blow to their fighting spirit. The aeroplanes would fly over advancing columns and fire ahead on their line of advance and occasionally bomb a position. This co-ordinated air and ground assault afforded the advancing troops the opportunity to make excellent use of air cover. The Bondelswarts bravely held their positions and continued to fire on the advancing force. This was not enough to stop the advance, and night found the forces between $400 \mathrm{~m}$ and 1,6 km from their objective. At the foot of the Guruchas hills in the west, the forces were holding the line in the Haib River bed, while the lower hills in the south, west and north were also occupied. ${ }^{34}$ 
The attack was halted for the night with the aim of commencing activities the next morning. Meanwhile, a cordon was established to prevent any Bondelswarts from escaping. This was ineffective as a band of 30 horsemen, 30 donkey-riders and 290 men on foot escaped to the southeast, driving a small number of stock in front of them. The bombing was resumed at dawn on 30 May, while the force advanced towards the defensive Bondelswarts positions. The order to cease fire was issued at 09:00, when the Bondelswarts raised white flags indicating their surrender. Hofmeyer's victory was short-lived when he realised that the prize only included 90 old males, and 700 women and children. Prinsloo and 45 mounted rifles were immediately mobilised to pursue the fleeing Bondelswarts. Balt was tasked to hold the waterholes surrounding the reserve and to sweep the area for any Bondelswarts and livestock. The stock rounded up totalled 13 970, which comprised 12470 sheep and goats, 800 head of cattle and 700 donkeys. The prisoners were escorted to Wortel, where arrangements were made to incarcerate them. Hofmeyer believed the uprising had been crushed and sent a telegram to Smuts confirming this. He subsequently returned to Kalkfontein South via Neufontein and awaited Prinsloo's report. ${ }^{35}$

Prinsloo followed the spoor of the fleeing Bondelswarts and reported the same day that they had split into three groups. The first was a group of approximately 70 men who were heading for Sperlingsputs, the second group comprised 150 men and were moving towards Kurnaims, and the third group consisted of 60 mounted men and 160 men on foot who were heading for Haibmund. Prinsloo decided to follow the last group and requested the occupation of the Swarthuk, Sperlingsputs and Kurnaims waterholes as well as reinforcements. The Administration's forces moved out to occupy the waterholes and Balt sent Lt. Jordaan and 75 mounted rifles to reinforce Prinsloo. Morris and the Bondelswarts were hampered from moving towards their traditional stronghold, the Fish River Canyon by the continued aerial reconnaissance. Morris adapted his plan and moved into the Gungunib Gorge ${ }^{36}$ with the aim of fighting the pursuing force with guerrilla tactics. The guerrilla tactics employed by the Bondelswarts were well known to Prinsloo and he remembered the lessons learned by the Germans 16 years earlier. He therefore decided not to meet Morris head-on, but to envelope Morris by moving at night via Ramans Drift, which cut Morris off from the Orange River and his southern escape route, preventing him from continuing his retreat. ${ }^{37}$ 
The aeroplane played a vital role in neutralising the advantage of the terrain that Bondelswarts used so effectively against the Germans. An assault was coordinated between Prinsloo and Jordaan, relayed via the pilots, to advance on the Bondelswarts and defeat them with aerial support. On 2 June, the aeroplanes, used to reconnaissance the route, found and engaged the Bondelswarts effectively. The attack wreaked havoc among the men and livestock, while the two forces continued their advance into the Gungunib Gorge. Morris concluded that their only hope was for a decisive defeat of their pursuers and decided to lead Prinsloo into an ambush at their secret waterhole, the Bergkamer. A group of approximately 160 Bondelswarts were not prepared to fight and moved down the Gungunib, skirting Prinsloo's forces that turned back to Goodhouse to regroup for the next day's advance, into the Union where they broke into smaller groups and disappeared. The final stand on 3 June was poised for an annihilation of the advancing forces that would be boxed in facing an entrenched force. However, the ambush failed with snipers opening fire too soon, and the Bondelswarts were defeated. Fifteen rifles were captured and 49 Bondelswarts were killed in the battle, including Morris, with only three injured. Following the spoor left by Cristiaan and his group, the force eventually caught up with them on 7 June in a gorge leading northwards into the plains. They surrendered with 150 men and 50 rifles. ${ }^{38}$

In the aftermath, Morris was vilified as the troublemaker by Cristiaan and Beukes, but their excuses did not prevent Cristiaan being sentenced to five years' hard labour, while Beukes testified for the Crown and was pardoned. The Bondelswarts were allowed to return to their reserve, and the captured livestock was returned to them, although many of the stock had stampeded into the desert and were never recovered. Action was taken to improve their economic plight. Work and rations were offered, medical assistance provided and the attendance of schools was encouraged. The few casualties on the side of the Administration's forces were attributed to the use of air power in support of ground operations. Close co-operation between the ground and air forces ensured that the aeroplanes were effectively utilised. The bombing and strafing of the Bondelswarts attributed to a loss of morale and sapped their fighting power. The aeroplane was unknown to the Bondelswarts and the psychological effect on them was tremendous. Hofmeyer therefore requested Van Ryneveld and his pilots to fly over reserves in the Keetmanshoop area on 15 June as a show of 
force. The aim was to prevent any other indigenous group attempting anything radical in the wake of the uprising. ${ }^{39}$

Hofmeyer was criticised severely for his handling of the uprising and for appointing himself as commander. Newspapers in South West Africa, South Africa and England questioned his appointment and noted his lack of military experience. The Labour Party criticised Smuts severely in Parliament. The uprising, in the wake of the Rand strike, provided the Labour Party with the opportunity to criticise Smuts further. Hofmeyer had acted on general guidelines and had been requested by Smuts to use constraint, but the leadership style of Smuts required him as Prime Minister to shoulder the blame. The Native Affairs Commission was asked to investigate the whole affair. ${ }^{40}$ The report portrayed the sequence of events, but the result was clouded by the differences of opinion between Drs Roberts and Loram and Gen. Lemmer. The opposition capitalised on the report and used it against Smuts. ${ }^{41}$

The British press questioned the use of force against the Bondelswarts in a mandated territory and went as far as to describe the event as a betrayal of the mandate trust. Sir Edgar Walton, the South African representative at the League of Nations, produced the reports on the incident on 5 September 1922. The League Assembly passed a resolution on 20 September 1922 for the Permanent Mandate Commission to investigate the matter. The uprising only received attention by the League Assembly on 12 May 1924, when Hofmeyer was requested to appear before the Permanent Mandate Commission. Their report to the League Council stated their disapproval of Hofmeyer's action in combining the role of military commander and the civil duty of Administrator. This removed the opportunity for the Bondelswarts to appeal to a higher authority or for an impartial judge to investigate the conduct of operations. Hofmeyer's actions were defended by Smuts and he remained the Administrator. ${ }^{42}$

\section{The Rehoboth Uprising, 1924-1925}

During the $18^{\text {th }}$ century, descendants of white colonial men and Khoisan women established communities that called themselves Basters (persons of mixed blood). ${ }^{43}$ Two Baster groups existed. One group eventually settled in East Griqualand under the leadership of Adam Kok, while the second 
group moved to Rehoboth, South West Africa, in 1870. The Rehoboth Basters formed a community based on constitutional and religious beliefs, which were maintained by organised structures such as their elected council. These structures provided a strong base from which they executed selfadministration. However, in the late $19^{\text {th }}$ century, the tenure of the permanent Baster community on the Rehoboth land was in jeopardy due to constant attacks by Namas and Hereros. The Basters' concern for security and protection from attacks paved the way for a Treaty of Protection and Friendship on 15 September 1885 and a treaty relating to defence between Germany and the Rehoboth Basters on 26 July 1895 after Germany had proclaimed South West Africa a German Protectorate in 1884. Germany provided protection while they provided men for military service. The Treaty furthermore recognised the rights and liberties of the Basters in Rehoboth. Internal matters were dealt with by the Baster Council, but disputes between the Basters and external parties were resolved by the German administration. Systematic encroachment of Baster territory and liberties reached breaking point during the First World War. Their employment as guards for prisoners of war violated the treaty, which prohibited their use against whites or deployment outside their territory. Germany rescinded the Treaties of 1885 and 1895 and the Basters sought Union protection. German forces mobilised to attack the Basters in May 1915 for their treasonous act of seeking assistance from the Union. The Basters made a final stand at Sam-Kubis against the Germans on 8 May and defended their position with 300 armed men. The Germans attacked SamKubis between sunrise and sunset, but retreated the next day leaving 30 Basters dead and wounded. ${ }^{44}$

The UDF did not mobilise to rescue the Basters because the Germans retreated from Rehoboth on 9 May 1915 and deployed to meet the Union Forces in strength. On 9 July 1915, the German Governor, Dr Theodor Seitz, and Col. Victor Franke, the Commander-in-Chief of the Schutztruppe, surrendered to Gen. Botha at Khorab. Martial law was instituted and the Basters remained in Rehoboth, working towards two goals: they wanted to regain their former independence and they wanted recover the land taken from them. Their hope of regaining independence was rekindled when Botha told Van Wyk during their discussion in April 1915, "that which you have, at least, you will keep". ${ }^{45}$ During the First World War, the status of the Basters, prior to hostilities with the German government, was reinstated. 
The Baster Council resumed their internal administrative affairs and retained their Baster magistrate and other officials who dealt with legal matters, the collection of taxes and the granting of liquor permits. The Baster community still hoped for full independence and continued their efforts to achieve this. ${ }^{46}$

However, on 9 January 1922, Hofmeyer submitted a draft agreement on how Rehoboth would be governed, after which he and the Baster Council held various rounds of negotiations, which ran aground in 1922, but was resumed on 16 July 1923. The two main issues that were discussed were the extent of their self-governance and the issue of land. These issues were not resolved and insignificant concessions were made to the Basters. The agreement returned the affairs of the Basters to what they had been when the Union invaded the territory in 1915. Hofmeyer's approach was no different from what it had been with other tribes, such as the Bondelswarts. The Basters only had limited authority over local matters and were subservient to the Administrator and his officials in legal and political affairs. The boundaries remained unchanged despite the Basters' objections. After the negotiations, the Council returned to Rehoboth to discuss the agreement with their community. The community was opposed to the agreement and the issue was put to the vote on 9 August 1923. The Agreement was rejected, but Hofmeyer made it clear that the agreement had to be signed by 16 August and even ratified it through Proclamation No. 28 of 1923, dated 28 September. Festivities to celebrate the agreement were boycotted by many Basters, and Samuel Beukes organised the opposition to form the Majority Party. The Majority Party rallied the community to reject the agreement and by November 1923, a campaign of passive resistance was instigated. Proclamations and orders by Administration officials were ignored and taxes were not paid. In the light of the repercussions from the Bondelswarts situation, nothing was done for fear of another backlash. ${ }^{47}$

The Majority Party organised elections and won all the seats in the Council and in the Parliamentary Council. The new Council refused to meet with the Administrator, who, in turn, on 5 May, issued Proclamation No. 13 of 1924. This Proclamation decreed that the old Council was the elected and properly constituted authority of Rehoboth and that a new election was to be held on 16 June 1924. The new Council refused to accept the Proclamation and the new elections were boycotted. The new Council continued to 
govern over Rehoboth, collecting taxes, making their own laws and issuing their own permits. The state of affairs reached boiling point when the new Council issued a Declaration of Independence on 1 December 1924, and the old Council called on the Administrator to intervene. ${ }^{48}$

On 10 December 1924, the Administration issued Proclamation No. 31 of 1924, which suspended the powers of the Captain and the Councils of the Basters and transferred power to the white magistrate, Maj. C.N. Manning. The Proclamation was accompanied by a strong police contingent, which stepped up patrols in the area. The new Council refused to submit to the conditions of Proclamation No. 31, which provided the Administration with ample opportunity to prosecute the offenders. Political considerations stemmed the Administration's immediate response and it was decided that the Basters would only be prosecuted for contravention of the law on cattle branding. Manning issued a notice that everybody in Rehoboth had to comply in terms of Proclamation No. 36 of 1921, Proclamation No. 14 of 1923 and Proclamation No. 15 of 1923 with the regulations regarding stock branding by 1 March 1925, or face the legal consequences. This included the Nama and Herero tribes also living in Rehoboth, who hired land from the Basters to breed stock or who worked for the Basters, and strongly supported the new Council. This notice was totally disregarded and the magistrate issued summonses to Toko Koopman, a member of the new Council, Piet Diergaart, the Baster magistrate, and Samuel Beukes, the leader of the Majority Party. They failed to appear in court and their arrest was ordered. The police, led by Sgt H.H. Erasmus, were unable to arrest them, because the community prevented them from entering the Council offices. The magistrate issued warrants of arrest for Jacobus Beukes, Petrus Job, Jacob Beukes, Daniel Beukes, David Swart, Frederick Draghoender, Hendrik Beukes and Nicolaas Draghoender for obstructing the police when they were attempting to arrest Koopman, Diergaart and Samuel Beukes. In a letter to Manning, dated 28 March, the new Council stated that the members would not be delivered to the court because the warrants that were issued were based on laws the Council refused to acknowledge. ${ }^{49}$

The Basters were on a collision course with the Administration, and the new Council called for all the Basters, Namas and Hereros in the district to assemble at Rehoboth. At least 600 men gathered to await the 
Administrator's reaction, which sent 157 policemen to Rehoboth under the command of Van Coller. They were armed with two Maxim and two Lewis machineguns and arrived at Rehoboth on 1 April 1925. Van Coller waited for the arrival of Col. M.J. de Jager, the SWA Force Commander, and the Citizen Force units from the Aroab, Bethanie, Gibeon, Keetmanshoop, Maltahöhe, Okahandja, Warmbad, Windhoek and Rehoboth districts, which were mobilised the same day. Proclamation No. 9 of 1925 instituted martial law on 3 April in Rehoboth and the surrounding districts. The mobilisation of the Citizen Force was hampered by a shortage of horses and coal as well as flooding of the railway lines after the summer rains. However, on 4 April 1925, within 72 hours, the Citizen Force of 36 officers, 428 noncommissioned officers and troops of which only 108 were mounted, were in a staging area close to Rehoboth. The UDF supported Administration by sending air force elements under the command of Van Ryneveld, which comprised three De Havilland aeroplanes and support personnel. ${ }^{50}$

Col. De Jager deployed his 621 men and surrounded the town of Rehoboth by first light on 5 April. Lt. Col. L. Rautenbach led A Squadron and deployed in the ridges west of the town. Capt. J. Balt and B Squadron deployed east of the town and C Squadron under the command of Capt. J.J. Smith was deployed as a cut-off group to prevent escape. The police were on standby for deployment in the town. The new Council received an ultimatum at 07:00, which demanded the unconditional surrender of everybody, the handing over of weapons and those Basters for whom warrants of arrest had been issued. The deadline was 08:00, and De Jager warned the new Council that he would use violence, if necessary, if they did not conform to the ultimatum. De Jager also requested them to remove all the non-combatants, women and children, to the north of the town to ensure their safety. The new Council requested an extension until 12:00 the next day, but De Jager refused. The new Council sent a second message to De Jager, in which they indicated their refusal to adhere to the ultimatum. The air force was given the signal to take off and to start circling the town at 08:00, the time of the deadline. Lt. Uys and his police contingent moved through the town towards the Council offices to execute the warrants of arrest. Uys handed the names to Jacobus Beukes, who, in turn, refused to deliver the men. Uys gave them five minutes to deliver the men and when they still refused, he ordered a charge on the Council offices. Everybody who stood in their way, including women, was removed and the men were 
arrested. The police rounded up the Basters with support from the aeroplanes, which did not fire a shot during their deployment. The planes provided the psychological edge by making diving sorties over the town, while the police arrested 632 members of the community. The uprising was suppressed within an hour and without the loss of life. De Jager ordered by right of martial law that all weapons, ammunition and explosives be surrendered. The police confiscated 177 rifles and various clubs and sticks. ${ }^{51}$

De Jager attributed the prevention of loss of life mainly to the use of aeroplanes, which scared the community and distracted them from focusing on the land force that was moving in. He further indicated that rapid mobilisation, the concentration of force, well-executed orders and the show of force had also contributed to a quick and successful suppression of the uprising. B and C Squadrons of the Citizen Force returned to their districts on 6 April. A Squadron and 100 policemen demobilised on 8 and 10 April respectively. The remaining police force patrolled the area until 22 April and by 30 April; the local police force was once again in charge of the area. Martial law was lifted on 11 May 1925. Hofmeyer received permission to use the air force for "show of force" demonstrations on 1 April 1925, as was done in 1922 after the Bondelswarts uprising. Bombing of targets and subsequent use of high explosive charges supplemented the air shows. The air shows were presented at Otjiwarongo, Tsumeb, Ondonga, Namatoni, Ovitot Reserve, Windhoek, Schiethof, Vaalgras Reserve and Keetmanshoop. The local tribes were intimidated by the air shows and feared the use of aeroplanes against them. However, the air shows gave away the element of surprise but, since the tribes lacked an adequate military response to neutralise the aeroplane, the areas remained free of uprisings. The air force element returned to Pretoria on 24 April $1925 .^{52}$

The group of 632 arrested at Rehoboth consisted of 289 Basters, 218 Hereros, 75 Namas and 50 Damaras. A group of 226 was set free, but the remaining 406 appeared before the Windhoek magistrate, A.R. Wilmot, in the Rehoboth magistrate's court between 7 and 9 April. Judgement was passed and those found guilty were sentenced from between $£ 30$ or three months in jail to $£ 2$ and one month in jail. Considering the impoverished nature of the Rehoboth, few of the fines were paid, and 319 were imprisoned, of whom 68 served the full sentence. During a visit by the 
Prince of Wales on 4 May 1925, the rest of the group was released from prison as a gesture of good will. Jacob de Villiers, a judge from the Appellate Division of the Union, was appointed to head a commission of inquiry into the uprising and submitted his report on 26 September 1926. The Basters continually sent petitions to the Permanent Mandates Commission until 1932, when the commission decided in favour of the Administration and indicated that the Basters did not really have independence and had therefore no grounds for further petitions. It also decided that the Basters were not fit to rule themselves and that the Administration should take appropriate action. The Administration placed the management of Rehoboth under the white magistrate, who was advised by an advisory council, which consisted of three elected and three appointed Basters. The suppression of the revolt and the subsequent air shows were a clear indication to the rest of the tribes in South West Africa that recalcitrant communities would be severely dealt with. ${ }^{53}$

\section{Military Action against Chief Ipumbu of the Ukuambi Tribe, 1932}

Apart from the trouble with the Bondelswarts and the Rehoboth Basters, the Administration had to deal with Chief Ipumbu who continuously disregarded its authority. Chief Ipumbu of the Ukuambi tribe in Ovamboland was not convinced by the Administration's show of force. He defied the authorities and launched a raid against the Ukuanyama tribe in November 1921. Subsequent talks with the chief failed and Hofmeyer fined Chief Ipumbu 20 head of cattle for his offence. Chief Ipumbu's modus operandi was to promise the payment; then always having excuses why he could not pay by the time of the deadline. Chief Ipumbu was sent an ultimatum in June 1923 to pay the fine and to surrender his arms and ammunition. He reluctantly paid only 10 head of cattle and refused to surrender his arms and ammunition. This set the stage for a punitive expedition against Chief Ipumbu, but in the light of the Bondelswarts debacle and the cost of a ground force, no military action was taken. Further negotiations were held and the chief eventually paid the remaining 10 head of cattle on 27 November $1923 .{ }^{54}$

The rest of the tribes in Ovamboland watched the debacle with great interest. The population of Ovamboland was estimated at about 150000 (see Figure 2: Boundaries of Ovamboland tribes). All the tribal leaders in 
Ovamboland, except Ipumbu, accepted the Administration's authority. It was in the best interest of the Administration to appear strong in the eyes of the tribal leaders and leading headmen to ensure obedience. Chief Ipumbu, however, did not openly oppose the Administration after he had paid the fine in 1923. His reign over his tribe continued and was characterised by tyranny and forced obedience. The chief of an Ovambo tribe was the ultimate authority and he ruled autocratically. Custom forbade any member to question his rule, and Chief Ipumbu exercised this authority with zeal. He also overstepped the legal boundaries and executed members without trial. The Finnish missionaries in Ovamboland complained of his actions and the neighbouring tribes severed ties with the Ukuambi. Several Ukuambi headmen left to reside with other tribes, but Chief Ipumbu continued to harass the missionaries and their converts. ${ }^{55}$

In July 1931, Chief Ipumbu ordered that Christian girls from his tribe be brought to him to participate in rites practised on the attainment of puberty. Some of the Christian girls discovered his intent to violate them and escaped capture. They sought sanctuary at the Finnish Mission, which Rev. Aho, head of the mission, provided. The relationship between the Mission and Chief Ipumbu was poor at the best of times and was further exacerbated by this turn of events. Revds Aho and Liljebad were occasionally shot at, but purposely missed. An indigenous teacher from the mission was also assaulted as the harassment continued. The Native Commissioner, Capt. C.H.L. Hahn, warned Chief Ipumbu to put an end to his misconduct, whereby the chief solemnly promised that it would never happen again. Ipumbu's promise was short-lived and trouble between the Mission and the chief erupted again on 30 December 1931. Chief Ipumbu intended to take one of his own daughters, Nekulu, as a wife. This was forbidden by tribal custom, but the chief was adamant and pursued the union. Nekulu escaped to the Mission where she received sanctuary. This entitled Nekulu to stay at the Mission as long as the patron of sanctuary, Revd Aho, occupied the Mission. Chief Ipumbu disregarded the custom and demanded the return of the girl, which was refused. Chief Ipumbu and 300 men armed with breech-loading rifles searched the Mission without success. They withdrew from the Mission, but maintained a cordon. Rifles and arrows were randomly fired at the Mission and its inhabitants. Nekulu was smuggled into a motorcar and was removed to Onandjokue, a Finnish 
Mission near Ondonga. Chief Ipumbu returned to his kraal after a thorough search of the Mission failed to deliver his intended bride. ${ }^{56}$

Because of these events, A.J. Werth, the Administrator, decided to fine Chief Ipumbu 10 head of cattle and requested an aircraft and a tank to assist his officials in enforcing their authority. He argued that a ground force would be too costly and would inevitably lead to bloodshed. He was of the opinion that a demonstration would be sufficient to cow the chief into paying the fine without any bloodshed. No tank was available, but Van Ryneveld, 24 men and three Westland Wapiti ${ }^{57}$ aircraft were dispatched from Pretoria. A special train with supplies for the Air Force left on 21 July and the aircraft took off on 23 July. The aircraft arrived in Windhoek on the evening of 23 July and a conference was immediately held with Van Ryneveld attending. Hahn was instructed on 24 July to relay to Chief Ipumbu that his initial fine of 10 head of cattle had been increased with an additional 40 head of cattle. He had to pay a total of 50 head of cattle for contempt of authority and non-compliance. If the chief did not pay the fine, Hahn was to inform him that he should surrender himself to the Administration to be dealt with in accordance with Section 1 of the Native Administration Proclamation No. 15 of 1928. If he failed to comply, he would ipso facto be deposed as Chief of the Ukuambi. This message would be delivered under air cover to indicate the Administration's willingness to carry out the threat. ${ }^{58}$

On 27 July, Hahn informed Chief Ipumbu, who listened attentively, of the newly imposed fine. He made numerous excuses for not paying the initial fine in time and committed himself to paying the 50 head of cattle on 1 August. The payment was not made and Hahn sent three messengers to the chief to deliver an ultimatum that he surrender at Mtswi on 3 August. Under customary law, the chief was not allowed to leave the boundary of his tribal lands. Mtswi was just inside Chief Ipumbu's tribal land close to the boundary. Hahn was awaiting Ipumbu's surrender, with the aeroplanes providing air cover, when he received a message from Ipumbu requesting him to be at a location about $13 \mathrm{~km}$ from the chief's kraal at 15:30. Hahn moved to the new location, but instead of the chief, 60 armed men awaited him as well as a total of 200 tribesmen hiding in the surrounding bush. He was requested to enter the kraal, but Hahn declined for fear of treachery and his own safety. Chief Ipumbu did not meet with Hahn. Hahn proceeded to 
give the armed detail of 60 Ukuambi a bombing demonstration and ordered them to inform Chief Ipumbu of their observations. Hahn returned to Otjiwarongo to brief the Administrator. ${ }^{59}$

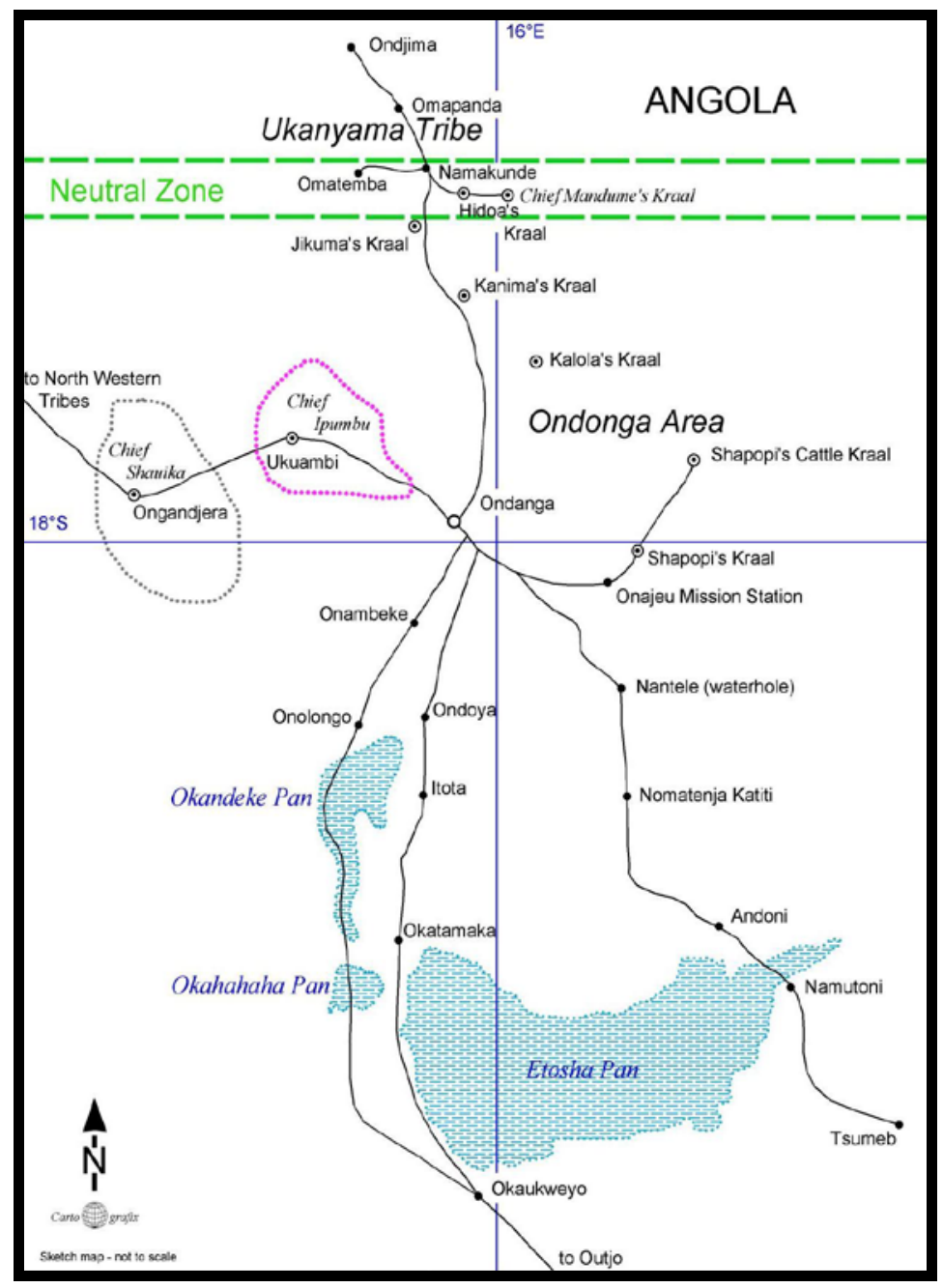

Figure 2: Boundaries of Ovamboland tribes. ${ }^{60}$ 
Werth, Van Ryneveld, Van Coller and Hahn met on 5 August to discuss further steps against Chief Ipumbu. The chief was seen as the central figure in the situation. The removal of Ipumbu as chief would eradicate the problems facing the Administration in Ovamboland. Ipumbu refused to accept the Administration's authority, had taken rifles from older men and given them to younger, reliable men, removed all the women and children, stationed picket lines around his kraal and had clear intentions of meeting any action with force. Three options on how to remove Chief Ipumbu by force were considered. The first option was to launch a surgical air strike and kill Ipumbu. The second option was to use the air strike to kill him and his bodyguards, and the third option was to discredit Ipumbu in the eyes of his tribe. To facilitate this, he had to be frightened of losing his tribal land, and his kraal had to be occupied and destroyed. Tribal custom would ensure that this was seen as a defeat for Ipumbu. The third option was decided on because it held the best chance of settling the dispute without bloodshed, which suited the Prime Minister, Gen. Hertzog. In order to execute an occupation of the kraal two armoured cars were requested on 5 August. ${ }^{61}$

The military objective of the operation was to ensure the surrender or capture of Chief Ipumbu. Hahn's intelligence network confirmed that the majority of the tribe of 8000 would welcome the intervention, but a small following of 300 men would probably support Chief Ipumbu. Hahn was instructed to try once more to settle the dispute, with the added request that the Ukuambi be disarmed. When the message was given to Chief Ipumbu, he sent an evasive reply and did not take the matter seriously. He was duly informed that he had disobeyed the Administration long enough and that he was no longer the recognised chief of the Ukuambi. He had to surrender immediately or else action would be taken to secure him dead or alive. Aerial reconnaissance continued while the Administration waited for the armoured cars to arrive. Two Crossley armoured cars ${ }^{62}$ with a crew of five men left Pretoria on 8 August under the command of Lt. J.B. Kriegler. They arrived in Windhoek on 11 August and acquired a six-wheeler Thorneycroft truck to assist their advance towards Ovamboland. The journey of $440 \mathrm{~km}$ was mostly sand and the armoured cars struggled to advance. The front wheels were solid and narrow and due to the weight of the car, sank into the soft sand repeatedly. One armoured car was left at Otjiwarongo with a broken water pipe, while the second car continued its demanding journey 
north. It eventually arrived at the staging area near Ondonga on 14 August and preparations were made for the upcoming assault. Kriegler was flown over the target area immediately after his arrival to show him his line of advance and the rendezvous point near the kraal. Hundreds of pamphlets were dropped over the kraal while the last reconnaissance flight was taking place. The pamphlet read "Ipumbu was instructed by the Administration to surrender himself. He has not done so. He is no longer chief of Ukuambi. Tomorrow (Monday) his kraal will be destroyed. Everybody is warned to keep away." The pamphlets were picked up and read by the inhabitants of the kraal. ${ }^{63}$

The air force and the armoured car had to work closely together and a code of signals was prepared. The system of communication included the following:

- The use of the Popham Panel, which consisted of a series of white canvas strips, put out on the ground to spell out a prearranged code to the pilot and observer;

- Message dropping by the aeroplane;

- Message pick-up by the aeroplane. (The message would be placed in a small canvas wrapping attached to a piece of string 7,5 m long. The string would be placed on two $2-2,4 \mathrm{~m}$ poles. The aeroplane was equipped with a hook or a weight attached to a string, which would catch onto the message wire as the pilot flew over. The observer would then pull up the message); and

- Wireless telephone between aircraft and armoured car. ${ }^{64}$

At 09:00 on the morning of 15 August, the armoured car with Hahn, Kriegler and the rest of the ground crew waited for the aeroplanes to commence bombing. Warriors around the kraal moved off as soon as the bombing commenced and the kraal was deserted. The end of the bombing was the signal for Kriegler to debus from the armoured car and to set the kraal on fire. This was hampered by a sudden attack of bees, which had been disturbed by the bombing. Very pistols were fired to smoke out the bees and eventually the kraal was set on fire. The perimeter was secured and large quantities of ammunition were found around the kraal where it had been left by the armed men when they departed. The ground force quickly 
ascertained that Chief Ipumbu had left early that morning with twenty men and gone to one of his cattle kraals, Mevethia, some $13 \mathrm{~km}$ from the main kraal. He left with orders that the men should stay until he returned. Upon hearing the news, the aeroplanes immediately took off for a follow-up operation with Hahn as observer to identify the kraal. Chief Ipumbu heard the aeroplanes approach and escaped into the bush towards the Portuguese border (Angola). ${ }^{65}$ The aeroplanes proceeded to bomb the kraal and killed 50 head of cattle owned by Chief Ipumbu. This was deemed appropriate, as this was equivalent to the fine that had not yet been paid. The aeroplanes returned to Ondonga, but the armoured car took up a defensive position outside the main kraal. ${ }^{66}$

Members of the Ukuambi tribe returned to the main kraal the day after the bombing. Van Ryneveld and Hahn addressed influential members of the tribe and informed them that their quarrel was with Ipumbu and not with the Ukuambi. They were to surrender their weapons and ammunition and call a tribal meeting for Friday, 19 August. Rifles and ammunition were surrendered during the course of the week and by Friday, 500 rifles had been handed in. The tribal meeting was attended by 1300 adult male Ukuambi members and Van Ryneveld. Smit, the Secretary for South West Africa, addressed them. Van Ryneveld explained the military aspect of the past events and Smit explained the Administration's future policy. In the light of the trouble with Ipumbu, no successor would be appointed. The Administration continued to implement a divide and rule policy in Ovamboland. The Ukuambi would be governed by the system successfully used by the Ukanyama. This entailed that the tribal area would be split into areas where a headman, approved and appointed by the Administration, would be in charge. The headmen would be obeyed, but the final authority would rest with the Administration's representative, the Native Commissioner, Hahn. The system was instantly accepted by the tribe and implemented in due course. A few days later news reached Van Ryneveld and Hahn that Ipumbu had been refused entrance into Angola. He was wandering around in the Ukanyama territory when trackers caught up with him. He was arrested and flown to Ondonga on 22 August where he was placed in custody. Tribal custom prevailed and Ipumbu had deposed himself from his chieftainship by leaving his tribal boundaries. Thus, the troublesome Ipumbu was deposed as chief without bloodshed. The armoured car returned to Pretoria on 23 August and the aeroplanes on 29 
August. The aeroplanes were utilised to visit all the tribal leaders in Ovamboland. These visits, under friendly conditions, were used to underline the Administration's position of power and to confirm their authority. The aeroplane, a powerful military and political resource, ensured this authority. ${ }^{67}$

\section{Conclusion}

The colonisation of the African continent by predominantly European powers instituted white dominance over indigenous African and Arab populations by the end of the nineteenth century. The technological advantage and the superior military organisation of the European settlers ensured military victory in the long run when it was pitted against inferior indigenous weapons and tactics. Britain, France and Germany were three prominent powers participating in the colonisation process, and resistance by local populations against their colonial governments was severely suppressed. The British style of policing a colony was prominent in South Africa, and later became entwined with the Dutch style present in South Africa before the British arrived. A fear of black uprisings troubled white settler communities, and the task of ensuring peace in the rural areas of South Africa fell upon the shoulders of the civil police, paramilitary and military units. They were responsible for suppressing unrest and policing race relations, which included not only white and black relations, but Afrikaner and British relations as well. The British style of colonial policing remained paramount. Local unrest against the governing structures was suppressed and the indigenous population policed to ensure peace. The new UDF continued this policing style from its inception in 1912. British military influence provided the permanent force of the UDF, the SAMR, with a specific role when it was not preparing to fight a conventional battle. The SAMR was to be applied as a mounted policing body in the rural areas. The pre-Union feature of military policing still prevailed in South Africa. The role and application of the UDF was a continuation of the military policing of the colonial regime and present in the forces within the SWA mandated territory. It provided the Union and the SWA Administration with the means to suppress popular uprisings against government rule, whether black or white. The UDF was subsequently put to the test in its peacetime role with the suppression of white uprisings in the Union with the Rebellion 
and the white mineworkers' strikes, but also indigenous uprisings in South West Africa.

The punitive measures against the Bondelswarts, Rehoboth and Ukuambi received criticism of varying degrees. The Bondelswarts affair received serious international criticism and was labelled as a betrayal of the sacred mandate trust. The Permanent Mandates Commission criticised Hofmeyer's actions and Smuts encountered political criticism in Parliament, led by the opposition leader, Hertzog. Yet Hertzog, as the new Prime Minister after the 1924 election, sanctioned expeditions against the Rehoboth Basters and Chief Ipumbu. The use of force to suppress internal uprisings in SWA was not an uncommon occurrence, but was viewed in a dim light by the League of Nations. As a C-class mandate, it was administered with the intention of providing for the indigenous people an opportunity for social development and the enhancement of material and moral wellbeing.

The importation of Union legislation and policies to SWA to control labour and to segregate according to race fermented growing opposition amongst the indigenous populations. Uprisings were inevitable as grievances were pushed aside. Obedience to the police and policies, racial, social and economic, was expected. Inevitably, conflicts arose when the Bondelswarts and the Rehoboth questioned policy regarding livestock and segregation. Chief Ipumbu, however, did not only contravene Union laws by directly opposing the Administration, but tribal laws too. The contravention of laws governing livestock, taxes and his defiance against the Administration placed the SWA Administration and the Union under pressure to resolve the problem quickly. Contravention of laws required that action be taken against some indigenous people of SWA, regardless of the merits of their grievances. The failure of Administration to take cognisance and act upon the grievances, only applying the prevailing legislation, led to punitive measures, which was a practiced and accepted way of dealing with uprisings at the time.

Traditional punitive forces consisted of mounted or foot soldiers, but the advent of the aeroplane supplemented this force structure. Joint airground operations were executed with success in SWA and the aeroplane and armoured cars were instrumental in their successes. The aeroplane was 
a force multiplier and was quickly mobilised when immediate action was necessary and it provided the authorities with the element of surprise when they used it against groups armed with rifles that had the home-ground advantage. Its use against the Rehoboth Basters and the Ukuambi ensured a quick resolution of the situation and limited casualties all round. The exception to this was the Bondelswarts, and the subsequent criticism was instrumental in the more careful approach with the Rehoboth Basters and the Ukuambi.

The tactical advantage to the military and police forces applied in suppressing the unrests were their ability to mobilise quickly and position themselves for a quick advance. The Bondelswarts were laid siege to when the waterholes were seized and they were prevented from launching attacks on outlying areas for supplies and ammunition. However, they managed to escape south with the aim to continue fighting guerrilla-style as they did with the Germans. The aeroplane hampered their ability to move undetected and prevented them from organising themselves effectively. The cooperation between the aeroplane and the ground forces provide an excellent description of the tactical application of joint operations. Another good example of this is the co-operation between the ground forces and the air force during the Rehoboth uprising. The aeroplane was instrumental in proving the psychological edge to the Administration and its use during the ground force advance to arrest the members with outstanding warrants directly contributed to no exchange of fire between opposing forces.

The traditional use of ground forces to subdue recalcitrant groups was waived in the actions against the Ukuambi. The aeroplane provided the alternative to ground forces, especially when the distance to Ovamboland was considered to be a tactical limitation for ground forces. However, ground forces were required for the operation since the decision was made to occupy Ipumbu's kraal, which the aeroplane was unable to do. Mounted troops gave way to two armoured cars, which provided another psychological edge. In hindsight, the armoured cars deployed with great difficulty and achieved limited tactical successes, but prevented the prolonged exposure of soldiers to possible enemy attacks. Its use provided ground forces needed to occupy the kraal without the need to send mounted soldiers while the aeroplane was the force multiplier that limited the amount of troops needed. 
1 FJ Burger. "Teeninsurgensie in Namibië: Die rol van die polisie”. MA thesis. University of South Africa, 1992, 95-96; G Cockram. South West African Mandate. Cape Town: Juta, 1976, 43, 125-127.

2 SANDFA (South African National Defence Force Archives), Secretary for Defence (hereafter DC) (2) 407, DC50681, Acting Secretary-General League of Nations to Prime Minister Union of South Africa forwarding the Mandate for South West Africa, 11 February 1921; Cockram op. cit., p. 127.

3 J Silverster et al. "Trees never meet: Mobility and containment - an overview 1915-1946”. In H Hayes et al (eds), Namibia under South African rule: Mobility and containment 1915-1946, Windhoek: Out of Africa Press, 23.

$4 \quad$ T Emmet, Popular resistance and the roots of nationalism in Namibia, 19151966. Basel: Schlettwein, 1999, 113.

$5 \quad$ Silvester op. cit., p. 23; Emmet, op. cit., p. 113.

6 Silvester op. cit., p. 24.

7 L Thompson. A history of South Africa. New Haven: Yale University Press, 1990, 52-53; TRH Davenport. South Africa: A modern history. Buffalo: University of Toronto Press, 1977, 21; A Lester et al. South Africa: Past, present and future. Harlow: Longman, 2000, 58.

8 T Pakenham. The scramble for Africa. Johannesburg: Jonathan Ball, 1991, xvxvii; G Pool. Die Herero-opstand, 1904-1907. MA thesis. Stellenbosch University, 1976, 1-17; H Strachan. European armies and the conduct of war. London: Allen \& Unwin, 1983, 77-79; IFW Beckett (ed). The roots of counterinsurgency, armies and guerrilla warfare, 1900-1945. New York: Blandford Press, 1988, 11; F Toase, F. “The French experience”. In Beckett op. cit., p. 41.

$9 \quad$ Beckett op. cit., p. 11; A Seegers. The military in the making of modern South Africa. London: IB Tauris, 1996, 1-7; E Roux. Time longer than rope: A history of the black man's struggle for freedom in South Africa. Madison: University of Wisconsin Press, 1964, 13-18; G Cawthra. Policing South Africa: The South African Police and the transition from apartheid. Cape Town: David Philip, 1993, 5; DE Omissi. Air power and colonial control: The Royal Air Force 1919-1939. Manchester: Manchester University Press, 1990, 3-4.

10 JD Brewer. Black and blue: Policing in South Africa. New York: Clarendon Press, 1994, 15.

11 Brewer op. cit., p. 37.

12 Seegers op. cit., pp. 1-2; Brewer op. cit., pp. 37-39; J Ploeger. "Hoofstukke uit die voor- en vroeë geskiedenis van die SAW”. Militaria 1/3. 1969. 36; WA Dorning. "'n Kort kroniek van die Suid-Afrikaanse Weermag, 1912-1987”. Militaria 17/7. 1987. 27.

13 Brewer op. cit., pp. 37-38; Cawthra op. cit., p. 8. Defence Act No. 13 of 1912. Statutes of The Union of South Africa. 196, 244, 246; Seegers op. cit., pp. 22 25.

14 SANDFA, DC(2) 320, 1.34285. Chief of the General Staff to District Staff Officers, 18 May 1918; SANDFA, DC(2) 320, 1.34285. Report by Lt Col TM Davidson on strike of native labourers at Burnside Collieries, 1 May 1919; SANDFA, DC(2) 320, 1.34285. Report by Capt. N Kennedy on the strike of native labourers at the Burnside Collieries, 25 April 1919; SANDFA, DC(2) 
320, 1.34285. Report by Lt. Col. TM Davidson, 30 April 1919; SANDFA, DC(2) 321, 10.34285. Under Secretary for Native Affairs to Secretary for Defence, 12 March 1919.

15 For more detail, please refer to DH Makobe. "Understanding the Bulhoek Massacre: Voices after the massacre and down the years”. Militaria 26/2. 1996; Union of South Africa. Interim and final reports of the Native Affairs Commission and telegram from Commissioner, South African Police, relative to "Israelites" at Bulhoek and occurrences in May, 1921, A.4/21, June 1921.

16 For more detail, please refer to Union of South Africa. Abridged annual report of the Department of Defence for the year end 30th June 1921, Pretoria, 1922; Union of South Africa. Report of the Judicial Commission of Inquiry into the causes of and circumstances relating to the recent rebellion in South Africa. 46-1916, 5 November 1916.

17 SANDFA, DC(2) 407, DC50681. Secretary for Defence to Chief of the General Staff, Demobilisation of the SWA Protectorate, 10 November 1919; SANDFA, DC(2) 407, DC 50681. Secretary for Defence to Chief of the General Staff, 6 November 1919.

18 Cockram op. cit., pp. 130-131; R Freislich. The last tribal war: A history of the Bondelswart Uprising which took place in South West Africa in 1922. Cape Town: Struik, 1964, 4-5; Union of South Africa. Report of the Commission ... op. cit., pp. 2-3.

19 Union of South Africa. Report of the Commission ... op. cit., p. 3.

20 Freislich op. cit., pp. 4-6; Cockram op. cit., pp. 127, 134-137; T Emmet. Popular resistance and the roots of nationalism in Namibia, 1915-1966. Basel: Schlettwein, 1999, 116-118; Union of South Africa. Report of the Commission ... op. cit., pp. 1-12; Union of South Africa. Report of the Administrator on the Bondelswarts Rising, 1922. 30/22, 22 June 1922. 2-3.

21 Freislich op. cit., pp. 7, 13-14; Union of South Africa. Report of the Commission ... op. cit., pp. 5-6, 13-14; Emmet op. cit., p. 121; Cockram op. cit., p. 139.

22 Union of South Africa. Report of the Commission ... op. cit., pp. 14-15; Emmet op. cit., p. 121; Cockram op. cit., pp. 139-140; Freislich op. cit., pp. 13, 15-16.

23 Freislich op. cit., pp. 16-17, 20-31; Cockram op. cit., pp. 140-141; Union of South Africa. Report of the Commission ... op. cit., pp. 16-22; Union of South Africa. Report of the Administrator ... op. cit., pp. 4-5; Lewis op. cit., p. 86.

24 Freislich op. cit., p. 18; SANA, PM 1/2/66, 167/22, Report by Maj. Van Coller of Military Operation against the Bondelswarts Hottentots, 26 May to 8 June 1922, 1-2; Freislich op. cit., p. 37; Lewis op. cit., p. 87.

25 Cockram op. cit., p. 144; Lewis op. cit., p. 88; SANDFA, Chief of the General Staff (hereafter CGS)(1) 12, 23, Native Disturbances at Kalkfontein, May 1922 Bondelswarts Rebellion, 2/52570, Telegram GM 1309, Chief of Union Defence Force to Minister of Defence, 23 May 1922; SANDFA, CGS(1) 12, 23, Native Disturbances at Kalkfontein, May 1922 Bondelswarts Rebellion, 9/52570, Telegram GM 1315, Chief of Union Defence Force to Administrator SWA, 25 May 1922; SANA op. cit., p. 2. 
26 SANA op. cit., p, PM 1/2/66, 167/22, Report by Maj. Van Coller of Military Operation against the Bondelswarts Hottentots, 26 May to 8 June 1922, 2

27 SANDFA, CGS(1) 12, 23, Native Disturbances at Kalkfontein, May 1922, Bondelswarts Rebellion, Report by Lt. Col. Nussey, 27 July 1922, 1-2; Lewis op. cit., p. 90.

28 SANA op. cit.

29 The Native Affairs Commission reported that the Bondelswarts had only one rifle between four fighting men.

30 Lewis op. cit., pp. 89-90; Freislich op. cit., p. 42.

31 Ibid., pp. 3-4; Lewis op. cit., p. 91; Freislich op. cit., p. 43.

32 Lewis op. cit., p. 91; Freislich op. cit., pp. 43-44.

33 SANA op. cit., pp. 6-8; Lewis op. cit., p. 92.

34 SANA op. cit., pp. 8-9; SANDFA, CGS(1) 12, 23, Native Disturbances at Kalkfontein, May 1922, Bondelswarts Rebellion, Report by Col. Sir P van Ryneveld, 2-3; Freislich op. cit., pp. 46-47; Lewis op. cit., p. 92.

35 SANA op. cit., pp. 8-11; SANDFA, CGS(1) 12, 23, Native Disturbances at Kalkfontein, May 1922, Bondelswarts Rebellion, Report by Col P van Ryneveld, 4; Freislich op. cit., pp. 50-51; Lewis op. cit., pp. 93-94.

36 The Gungunib Gorge was 15 miles (24,15 km) long and 20 to $50 \mathrm{ft}$ (7 to $17 \mathrm{~m}$ ) wide at the base, with precipitous sides rising to $2000 \mathrm{ft}$ (700 m).

37 SANA op. cit., p. 12; Freislich op. cit., p. 51; Lewis op. cit., pp. 95-96.

38 SANA op. cit., pp. 11-13; SANDFA, CGS(1) 12, 23, Native Disturbances at Kalkfontein, May 1922, Bondelswarts Rebellion, Report by Col. Sir P van Ryneveld, 4-5; Freislich op. cit., pp. 71-83; Lewis op. cit., pp. 96-97.

39 SANDFA, CGS(1) 12, 23, Native Disturbances at Kalkfontein, May 1922, Bondelswarts Rebellion, Telegram 52570(GI), Maj. Prins to Chief of Union Defence Force, 9 June 1922; SANA op. cit., pp. 18-19; SANDFA, CGS(1) 12, 23, Native Disturbances at Kalkfontein, May 1922, Bondelswarts Rebellion, Report by Col. Sir P van Ryneveld, 10; Freislich op. cit., pp. 50, 62, 81.

40 This was the same Commission that investigated the Bulhoek incident. Senator Dr AW Roberts chaired the Commission of Enquiry with Dr CT Loram and Gen. Lemmer as members.

41 AM Davey. The Bondelzwarts Affair: A study of the repercussions, 1922-1959. Pretoria: University of South Africa, 1961, 9; Hancock op. cit., p. 109; T Cameron. Jan Smuts: An illustrated biography. Cape Town: Human \& Rousseau, 1994, 95.

42 Cockram op. cit., p. 144; Davey op. cit., pp. 15-17; Cameron op. cit., p. 95; Hancock op. cit., p. 108.

43 English translation: "Bastards".

44 Emmet op. cit., p. 155; RG Britz et al. A concise history of the Rehoboth Basters until 1990. Windhoek: Klaus Hess Publishers, 1999, 10-11, 19-27; Union of South Africa. Report of the Rehoboth Commission. 41/26, 20 September 1926. 57-58.

45 Emmet op. cit., p. 155.

46 Britz op. cit., pp. 28-30; Pearson op. cit., pp. 149-157.

47 Britz op. cit., p. 30; Pearson op. cit., pp. 153-169, 176-178; I Goldblatt. History of South West Africa from the beginning of the nineteenth century. 
Cape Town: Juta, 1971, 222; Britz op. cit., pp. 28-31, 159; Emmet op. cit., pp. 158-159.

48 Goldblatt op. cit., p. 222; Pearson op. cit., pp. 176-188; Britz op. cit., pp. 3133, 159; Emmet op. cit., p. 159.

49 GJJ Oosthuizen. "Die Rehoboth-basters binne die konteks van die staatkundige verhoudinge tussen Suidwes-Afrika en Suid-Afrika, 1915-1939”. DLitt dissertation. University of Potchefstroom, 1993, 183-186; Emmet op. cit., p. 159; Britz op. cit., pp. 32-33; Goldblatt op. cit., pp. 222-223; Pearson op. cit., pp. 188-191.

50 Oosthuizen op. cit., pp. 192-198, 200-202, 204-206; Pearson op. cit., pp. 194197.

51 SANDFA, CGS 42, 7/62, Aeroplanes for Rehoboth Friction in South West Africa, 1925, Letter 2/1925, Chief of General Staff to Imperial General Staff, 19 August 1925, 1, 8-9; Oosthuizen op. cit., pp. 192-208; Pearson op. cit., pp. 194-199.

52 SANDFA, CGS 42, 7/62, Aeroplanes for Rehoboth Friction in South West Africa, 1925, Letter 2/1925, Chief of General Staff to Imperial General Staff, 19 August 1925, 9; Oosthuizen op. cit., pp. 209-211.

53 Emmet op. cit., pp. 160-162; Oosthuizen op. cit., pp. 210-212; Britz op. cit., p. 36; Pearson op. cit., pp. 199-200; Goldblatt op. cit., pp. 223-224.

54 SANDFA, Governor General (hereafter GG) 289, 4/300, South West Africa, General Insurrection of Native Chief Ipumbu, Report by Administrator to Governor-General, 2 September 1932, 1-6; Pearson op. cit., p. 170.

55 SANDFA, GG 289, 4/300, South West Africa, General Insurrection of Native Chief Ipumbu, Report by Administrator to Governor-General, 2 September 1932, 6-11; SANDFA, CGS(1) 43, DAS 7/13/1, Operations, Campaign and Stores in South West Africa, July 1932, Report by Col. Sir P van Ryneveld, 15 December 1932, 2-5.

56 Ibid.; SANDFA, CGS(1) 43, DAS 7/13/1, Operations, Campaign and Stores in South West Africa, July 1932, Report by Col. Sir P van Ryneveld, 15 December 1932, 2-5; SANDFA, CGS(1) 43, 63, Native Trouble Ovamboland 1932, Telegram Administrator to Prime Minister, 16 July 1932, 1.

57 The SAAF bought four Westland Wapiti Mk. IIA in 1929 and 27 were built in South Africa from 1931. J Teeuwen. "British aircraft of World War II". 10 April 2003. <http://www.jaapteeuwen.com/ww2aircraft/WESTLAND.htm> Accessed on 10 July 2004.

58 SANDFA, GG 289, 4/300, South West Africa, General Insurrection of Native Chief Ipumbu, Report by Administrator to Governor-General, 2 September 1932, 17-18; SANDFA, CGS(1) 43, 23, Native Trouble Ovamboland 1932, Telegram Administrator to Prime Minister, 25 July 1932, 1-2; SANDFA, CGS(1) 43, DAS 7/13/1, Operations, Campaign and Stores in South West Africa, July 1932, Report by Col. Sir P van Ryneveld, 15 December 1932, 2-7.

59 SANDFA, CGS(1) 43, DAS 7/13/1, Operations, Campaign and Stores in South West Africa, July 1932, Report by Col. Sir P van Ryneveld, 15 December 1932, 7-12; SANDFA, GG 289, 4/300, South West Africa, General Insurrection of Native Chief Ipumbu, Report by Administrator to GovernorGeneral, 2 September 1932, 18-20; SANDFA, CGS(1) 43, 23, Native Trouble 
Ovamboland 1932, Telegram Administrator to Prime Minister, 4 August 1932, 1.

60 SANDFA, CGS 63/1, Native Tribe, Ovamboland, 1932.

61 SANDFA, CGS(1) 43, DAS 7/13/1, Operations, Campaign and Stores in South West Africa, July 1932, Report by Col. Sir P van Ryneveld, 15 December 1932, 11-13; SANDFA, GG 289, 4/300, South West Africa, General Insurrection of Native Chief Ipumbu, Report by Administrator to GovernorGeneral, 2 September 1932, 20-21; SANDFA, CGS(1) 43, 23, Native Trouble Ovamboland 1932, Telegram Chief of Union Defence Force to Col. Sir Van Ryneveld, 5 August 1932, 1.

62 Crossley 1924 MK I/L/India Armoured Car.

63 SANDFA, CGS(1) 43, 23, Native Trouble Ovamboland 1932, Correspondence from the Chief of the General Staff to the Adjutant General, 9 August 1932, 1; SANDFA, GG 289, 4/300, South West Africa, General Insurrection of Native Chief Ipumbu, Report by Administrator to Governor-General, 2 September 1932, 21-22; SANDFA, Adjutant General (hereafter AG) (114) 21, KA/UVM, Operation Ipumbu by Brig. Gen. JB Kriegler, 7 August 1976, 1-2; SANDFA, CGS(1) 43, DAS 7/13, Armoured Vehicles - Ovamboland Expedition, Report by Capt. JB Kriegler, 13 September 1932, 1-2; SANDFA, CGS(1) 43, DAS 7/13/1, Operations, Campaign and Stores in South West Africa, July 1932, Report by Col. Sir P van Ryneveld, 15 December 1932, 13-15.

64 SANDFA, AG(114) 21, KA/UVM, Operation Ipumbu by Brig. Gen. JB Kriegler, 7 August 1976, 2-7.

65 Portugal was the colonial power in Angola from the 12th Century.

66 SANDFA, CGS(1) 43, DAS 7/13/1, Operations, Campaign and Stores in South West Africa, July 1932, Report by Col. Sir P van Ryneveld, 15 December 1932, 12-17; SANDFA, GG 289, 4/300, South West Africa, General Insurrection of Native Chief Ipumbu, Report by Administrator to GovernorGeneral, 2 September 1932, 22-24; SANDFA, AG(114) 21, KA/UVM, Operation Ipumbu by Brig. Gen. JB Kriegler, 7 August 1976, 7-11.

67 SANDFA, GG 289, 4/300, South West Africa, General Insurrection of Native Chief Ipumbu, Report by Administrator to Governor-General, 2 September 1932, 15-27; SANDFA, CGS(1) 43, 23, Native Trouble Ovamboland 1932, Col. Sir P van Ryneveld to Chief of Union Defence Force, 23 August 1932, 1; SANDFA, CGS(1) 43, DAS 7/13/1, Operations, Campaign and Stores in South West Africa, July 1932, Report by Col. Sir P van Ryneveld, 15 December 1932, 17-19. 